\title{
ANALISIS KAPASITAS DAN KECEPATAN ARUS BEBAS BERDASARKAN MKJI DI RUAS JALAN GATOT SUBROTO
}

\author{
Zahwa Nur Raudah', Widodo Kushartomo ${ }^{2}$, dan Najid ${ }^{3}$ \\ ${ }^{1}$ Program Studi Sarjana Teknik Sipil, Universitas Tarumanagara, Jl. Letjen S. Parman No.1 Jakarta \\ zahwa.325150206@stu.untar.ac.id \\ ${ }^{2}$ Program Studi Sarjana Teknik Sipil, Universitas Tarumanagara, J1. Letjen S.Parman No.1 Jakarta \\ widodo@untar.ac.id \\ ${ }^{3}$ Program Studi Sarjana Teknik Sipil, Universitas Tarumanagara, Jl. Letjen S. Parman No.1 Jakarta \\ najid@ft.untar.ac.id
}

\begin{abstract}
The congestion that occurs in the city of Jakarta is caused by the large number of four-wheeled and two-wheeled vehicle drivers who fill the road, so that the volume increases which results in a congestion on the road segment. In this research, we will discuss about the capacity and free flow on Gatot Subroto street in both directions. The data needed to calculate the capacity and speed of free flow is the volume of the vehicle, the speed and density of the road sections. This research was conducted in the morning to evening, each 2 hours with a time interval of 15 minutes. The calculation in the study used the MKJI 1997 method and the Greenshield method. Obtained from the Greenshield model the highest $R^{2}$ value in the morning to evening is 0,9943 with a VS value $=40.011-0.0396 D$ for direction 1 and a value of $C=10107$ pcu / hour while the $R^{2}$ value for direction 2 is 0,9193 with VS=66,9928$0,1583 D$ for direction 2, the value of $C=7088 \mathrm{pcu} /$ hour. By using the MKJI 1997 method, the value of C = 4890,6 pcu / hour was obtained.
\end{abstract}

Keywords: Gatot Subroto; Capacity; Speed; MKJI; Greenshield

\begin{abstract}
ABSTRAK
Kemacetan yang terjadi di Kota Jakarta disebabkan banyaknya pengemudi kendaraan roda empat maupun roda dua yang memenuhi ruas jalan tersebut, sehingga volume meningkat yang mengakibatkan terjadinya kepadatan pada ruas jalan tersebut. Pada penelitian ini, akan dibahas mengenai kapasitas dan kecepatan arus bebas di ruas jalan Gatot Subroto di kedua arah. Data yang dibutuhkan untuk menghitung kapasitas dan kecepatan arus bebas adalah volume kendaraan,kecepatan dan kepadatan ruas jalan tersebut. Penelitian ini dilakukan pada pagi hari hingga sore hari , masing masing setiap 2 jam dengan interval waktu 15 menit. Perhitungan pada penelitian menggunakan metode MKJI 1997 dan metode Greenshield. Didapat dari model Greenshield nilai $\mathrm{R}^{2}$ tertinggi pada saat pagi hingga sore hari yaitu 0,9943 dengan nilai $\mathrm{VS}=40,011-0,0396 \mathrm{D}$ untuk arah 1 dan nilai $\mathrm{C}=10107 \mathrm{smp} / \mathrm{jam}$ sedangkan nilai $\mathrm{R}^{2}$ untuk arah 2 0,9193 dengan $\mathrm{VS}=66,9928-0,1583 \mathrm{D}$ untuk arah 2 nilai $\mathrm{C}=7088 \mathrm{smp} / \mathrm{jam}$. Dengan menggunakan metode MKJI 1997 didapat nilai C = 4890,6 smp/jam.
\end{abstract}

Kata kunci: Gatot Subroto; Kapasitas; Kecepatan; MKJI; Greenshield

\section{PENDAHULUAN}

Transportasi adalah kegiatan pemindahan barang dan penumpang dari suatu tempat ketempat lain menurut (Salim, 2000). Transportasi sudah menjadi sesuatu hal yang penting dalam kehidupan manusia khususnya dalam mempersingkat hal yang penting dalam kehidupan manusia khususnya dalam mempersingkat waktu untuk mencapai suatu tempat. Tidak hanya untuk mengefisienkan waktu pemindahan manusia, namum membantu juga dalam pemindahan barang.

Jakarta merupakan salah satu kota terbesar di Indonesia, tingginya urbanisasi secara tidak langsung dapat dikatakan sebagai akibat dari tidak meratanya pertumbuhan wilayah di Indonesia, antara daerah pedalaman dengan daerah perkotaan. Semakin besar perbedaan tingkat pertumbuhan wilayah tersebut, semakinn tinggi pula tingkat urbanisasi yang pada gilirannya akan menimbulkan beberapa permasalahan perkotaan, khususnya di sektor transportasi. 
Tambahan lagi, proses urbanisasi dan industrialisasi selalu terjadi secara hampir bersamaan terutama di negara yang beralih dari negara pertanian ke negara industri menurut (Tamin, 2000).

Penduduk di Kota Jakarta mempunyai mobilitas tinggi atau berpindah dari suatu tempat ke tempat lainnya membutuhkan transportasi. Perpindahan yang dilakukan penduduk di Jakarta membutuhkan sarana transportasi yang dapat menunjang dari berbagai aspek yang dibutuhkan. Namun saat ini, penduduk di kota Jakarta lebih menyukai menggunakan kendaraan pribadi dibandingkan dengan transportasi umum. Masih banyaknya pengguna kendaraan pribadi salah satu pemicu terjadinya kemacetan di Jakarta yang semakin parah.

Adanya kegiatan trasnportasi maka akan terjadi pergerakan lalu lintas, adanya pergerakan lalu lintas terdapat tiga variabel utama yang sangan menentuka yaitu volume (flow), kecepatan (speed), kepadatan (density). Hubungan ketiga variabel ini dapat diketahui arus lalu lintas maksimum dengan kata lain kapasitas jalan tersebut. Metode Indonesia yang digunakan untuk menganalisis kapasitas ruas jalan adalah Manual Kapasitas Jalan Indonesia (MKJI 1997), perhitungan dengan menggunakan metode MKJI 1997 memiliki beberapa faktor untuk penyesuain yang perlu dikaji dalam penentuan kapasitas ruas jalan perkotaan. Faktor penyesuaian tersebut berupa kapasitas dasar, lebar jalan, hambatan sampingm dan ukuran kota.

Jalan Gatot Subroto merupakan jalan arteri di kota Jakarta yang memiliki volume/arus kendaraan yang cukup tinggi. Disepanjang jalan ini terdapat perkantoran, perbelanjaan dan tempat usaha yang menyebabkan bertumpuknya kendaraan pada ruas jalan tersebut. Volume, kecepatan dan kepadatan lalu lintas selain untuk perencanaan digunakan untuk mengevaluasi jalan. Suatu jalan dikatakan macet apabila arus lalu lintas yang melewati ruas jalan tersebut mengakibatkan kecepatan bebas ruas jalan tersebut mendekati $0 \mathrm{~km} / \mathrm{jam}$ atau bahkan menjadi $0 \mathrm{~km} / \mathrm{jam}$ sehingga mengakibatkan antrian. Kemacetan terjadi pada jam puncak (peak hour), atau hubungan antara volume setiap jam dan angka arus maksimum (Rusdiyanto, 2014). Maka dari itu kecepatan, kepadatan dan volume sangat penting untuk mengevalusi jalan.

Adanya tingkat pengguna jalan yang cukup padat, maka dari itu dapat diidentifikasi masalah pada ruas jalan tersebut yaitu, bagaimana hubungan kepadatan dan kecepatan lalu lintas di jalan tersebut, menentukan kapasitas jalan dan kecepatan arus bebas berdasarkan MKJI 1997. Sehingga nantinya dapat mengaplikasikan model Greenshield pada kondisi hubungan kepadatan dan kecepatan, dan dapat mengevaluasi ruas jalan tersebut dikedua arah.

Maka dari itu, penulis secara khusus akan membahas dan meneliti lebih dalam tentang Jalan Gatot Subroto. Penelitian ini ditulus berdasarkan Manual Kapasitas Jalan Indonesia 1997 ( MKJI 1997 ), data yang diperoleh dari penelitian sebelumnya dikarenakan adanya wabah yang tidak bisa melanjutkan penelitian di semester ini. Jalan Gatot Subroto dipilih karena merupakan salah satu jalan protokol termacet di kota Jakarta pada pagi dan sore hari (rush hour) serta banyak dilalui oleh berbagai kendaraan umum maupun kendaraan pribadi.

\section{Hambatan samping}

Hambatan samping adalah dampak terhadap kinerja lalu lintas yang berasl dari aktivitas samping segmen jalan. Hambatan samping yang umumnya sangat mempengaruhi kapasitas jalan adalah pejalan kaki, angkutan umum, kendaraan lain berhenti, kendaraan tak bermoto, kendaraan masuk dan keluan dari fungsi tata guna lahan di samping. Tingkat hambatan samping telah dikelompokan dalam lima kelas dari kondisi sangat rendah, rendah, sedang, tinggi, dan sangat tinggi.

\section{Kecepatan arus bebas (free flow)}

Arus bebas (FV) berdasarkan (MKJI,1997) didefinisikan sebagai kecepatan pada tingkat arus nol, yaotu kecepatan yang akan dipilih oleh pengemusi jika mengendarai kendaraan bermotor tanpa dipengaruhi oleh kendaraan bermotor lain di jalan

$$
\mathrm{FV}=(\mathrm{FVo}+\mathrm{FVw}) \times \mathrm{FFV}_{\mathrm{SF}} \times \mathrm{FFV}_{\mathrm{CS}}
$$

dengan $\mathrm{FV}=$ kecepatan arus bebas kendaraan ringan $(\mathrm{km} / \mathrm{jam}), \mathrm{FVo}=$ kecepatan arus bebas dasar kendaraan ringan $(\mathrm{km} / \mathrm{jam}), \mathrm{FV}_{\mathrm{W}}=$ faktor penyesuaian lebar jalur lalu lintas efektif $(\mathrm{km} / \mathrm{jam}), \mathrm{FFV}=$ faktor penyesuain kondisi hamabtan samping dan $\mathrm{FFV}_{\mathrm{CS}}=$ faktor penyesuaian ukuran kota/jumlah penduduk (perkalian)

\section{Kapasitas jalan}

Kapasitas jalan berdasarkan (MKJI,1997) adalah kemampuan ruas jalan untuk menamung arus atau volume lalu lintas yang ideal dalam satuan waktu tertentu, dinyatakan dalam jumlah kendaraan yang melewati potongan jalan tertentu dalam satu jam (kend/jam), atau dengan mempertimbangkan berbagai jenis kendaraan dalam perhitungan kapasitas menggunakan satuan mobil penumpang per jam atau (smp/jam). 
Pada saat arus rendah kecepatan lalu lintas kendaraan bebas tidak ada gangguan dari kendaraan lain, semakin banyak kendaraan yang melewati ruas jalan, kecepatan akan semakin turun sampai suatu saat tidak bisa lagi arus / volume lalu lintas beetambah, disinilah kapasitas terjadi. Setalah itu arus akan berkurang terus dalam kondisi arus yang dipaksakan sampai suatu saat kondisi macet total, asrus tidak bergerak dan kepadatan tinggi.

$$
\mathrm{C}=\mathrm{C}_{\mathrm{O}} \times \mathrm{FC}_{\mathrm{W}} \times \mathrm{FC}_{\mathrm{SP}} \times \mathrm{FC}_{\mathrm{SF}} \times \mathrm{FC}_{\mathrm{CS}}
$$

Dengan $\mathrm{C}=$ kapasitas, $\mathrm{Co}=$ kapasitas dasar, $\mathrm{FCw}=$ faktor penyesuaian lebar jalau lalu - lintas, $\mathrm{FC}_{\mathrm{SP}}=$ faktor penyesuain pemisah arah, $\mathrm{FC}_{\mathrm{SF}}=$ faktor penyesuain hambatan samping dan $\mathrm{FC}_{\mathrm{CS}}=$ faktor penyesuain ukuran kota.

Kapasitas dasar adalah jumlah kendaraan maksimum yang dapat melintasi suatu penampang pada suatu jalar atau jalan selama 1 (satu) jam, dalam keadaan jalan dan lalu lintas mendekati ideal yang tercapai.

\section{Greenshield}

Greenshield mendasarkan modelnya pada asusmsi hubungan kecepatan dan kepadatan yang merupakan hubungan linier. Model Greenshield didasarkan pada hasil studi Greenshield pada jalur jalan kota Ohio AS pada tahun 1934 dimana kondisi arus lalu lintas yang ada memenuhi persyaratan penelitian karena tidak adanya gangguan serta adanya kondisi bebas kendaraan (steady state condition) (Pribadi, 2004).

\section{METODE PENELITIAN}

Tahapan penelitian mendeskripsikan keselurahan proses penelitian ini dengan fokus di Jalan Gatot Subroto. Tahap awal penelitian ini dengan mengumpulkan data melalui metode observasi langsung pada ruas jalan yang dilakukan pada penelitian sebelumnya dikarenakan untuk melanjutkan penelitian saat ini adanya keadaan yang tidak memungkinkan untuk meneliti ruas Jalan Gatot Subroto, kemudian data tersebut akan diolah dalam kategori per waktu yaitu pagi,siang, dan sore hari. Data yang diambil dengan metode observasi langsung yaitu kecepatan kendaraan, jumlah kendaraan bermotor roda dua maupun roda empat,dan sebagainya.

Data yang diperoleh dari peneltian sebelumnya berfungsi untuk menganalisis kapasitas jalan yang terjadi pada setiap ruas Jalan Gatot Subroto. Sehingga hasil akhir dari penelitian ini dapat menghasilkan nilai kapasitas jalan, kecepatan arus bebas dan dapat mengevaluasi jalan tersebut.

\section{Metode pengumpulan data}

Metode observasi langsung pada ruas jalan Gatot Subroto yang dilakukan pada penelitian sebelumnya adalah salah satu metode primer dalam penelitian ini. Penelitian ini juga banyak mengandung beberapa aspek seperti volume lalu lintas, kecepatan rata - rata, kapasitas jalan, dan tingkat pelayanan jalan di ruas Jalan Gatot Subroto. Data pada penulisan kali ini merupakan data yang dilakukan penelitian sebelumnya. Pengumpulan data juga didapat dari data sekunder yaitu data literatur dan data instansional, dengan mengacu kepada Manual Kapasitas Jalan Indonesia 1997. Data yang dikumpulkan nantinya akan dianalis untul mendapatkan model dengan metode pendekatan Greenshield.

\section{HASIL DAN PEMBAHASAN}

Dari hasil analisi yang telah dilakukan pada penelitian ini, didaptkan nilai kapasitas jalan dan kecepatan arus bebas berdasarkan MKJI 1997. Hasil analisis dibandingkan dengan pendekatan nilai kapasitas dengan metode Greenshield untuk menentukan hasil yang lebih cocok untuk ruas jalan tersebut. Hasil pengamatan yang dilakukan dikompilasikan untuk membuat regresi linear hubungan kepadatan lalu lintas dan kecepatan lalu lintas disetiap ruas jalan dengan bantuan program microsoft excel. Dari data hubungan kepadatan lalu lintas dan kecepatan lalu lintas dapat menghitung kapasitas yang terjadi pada setiap ruas jalan tersebut, yang dimana nantinya akan dibandingkan dengan perhitungan MKJI 1997 untuk di evaluasi. Untuk mengetahui nilai analisi kapasitas jalan Gatot Subroto sebrang JCC Senayan dapat dilihat pada Tabel 1, sedangkan untuk hasil analisis kapasitas jalan Gatot Subroto depan JCC Senayang dapat dilihat pada Tabel 2. Selain menganalisis dengan menggunakan metode MKJI 1997 dapat menganalisi menggunakan metode Greenshield, untuk hasil analisis dengan pendekatan menggunakan metode Greenshield sebrang JCC Senayan pada Tabel 3 dan Tabel 4 untuk hasil analisis dengan pendekatan metode Greenshield depan JCC Senayan. 
Tabel 1. Analisis kapasitas jalan Gatot Subroto sebrang JCC Senayan

\begin{tabular}{ccccccccc}
\hline Waktu & $\begin{array}{c}\text { Jarak } \\
(\mathrm{m})\end{array}$ & $\begin{array}{c}\text { Tidak } \\
\text { Bermotor }\end{array}$ & Parkir & Keluar/Masuk & $\begin{array}{c}\text { Pejalan } \\
\text { Kaki }\end{array}$ & Hambatan & $\begin{array}{c}\text { Kode } \\
\text { Hambatan }\end{array}$ & C \\
\hline $07.00-09.00$ & 200 & 12 & 43 & 0 & 0 & 47,8 & VL & 4890,6 \\
$13.00-15.00$ & 200 & 6 & 34 & 0 & 0 & 36,4 & VL & 4890,6 \\
$16.00-18.00$ & 200 & 4 & 36 & 0 & 0 & 37,6 & VL & 4890,6 \\
\hline
\end{tabular}

Dapat diketahui bahwa nilai kapasitas jalan (C) sebesar 4890,6 smp/jam dengan hambatan samping sangat rendah (very low)

Tabel 2. Analisis kapasitas jalan Gatot Subroto depan JCC Senayan

\begin{tabular}{ccccccccc}
\hline Waktu & $\begin{array}{c}\text { Jarak } \\
(\mathrm{m})\end{array}$ & $\begin{array}{c}\text { Tidak } \\
\text { Bermotor }\end{array}$ & Parkir & Kelua/Masuk & $\begin{array}{c}\text { Pejalan } \\
\text { Kaki }\end{array}$ & Hambatan & $\begin{array}{c}\text { Kode } \\
\text { Hambatan }\end{array}$ & C \\
\hline $07.00-09.00$ & 200 & 14 & 36 & 33 & 0 & 64,7 & VL & 4890,6 \\
$13.00-15.00$ & 200 & 6 & 22 & 36 & 0 & 48,9 & VL & 4890,6 \\
$16.00-18.00$ & 200 & 15 & 28 & 48 & 0 & 57,6 & VL & 4890,6 \\
\hline
\end{tabular}

Nilai hambatan yang tertera pada kolom sudah dikalikan dengan faktor pengalinya, dan didapat kode hambatan yang sama yaitu VL (very low).

Tabel 3. Analisis dengan pendekatan metode Greenshield sebrang JCC Senayan

\begin{tabular}{ccccccc}
\hline Waktu & Sff & B & Dj & C & $R^{2}$ & Model \\
\hline $07.00-09.00$ & 17,4345 & $-0,00848$ & 1227,172 & 5349 & 0,3961 & $17,4345-0,0084 \mathrm{D}$ \\
$13.00-15.00$ & 58,4439 & $-0,1338$ & 436,8004 & 6382 & 0,8648 & $58,4439-0,1338 \mathrm{D}$ \\
$16.00-18.00$ & 22,4811 & $-0,0188$ & 1195,8032 & 6721 & 0,9913 & $22,4811-0,0188 \mathrm{D}$ \\
Gabungan & 40,0110 & $-0,0396$ & 1010,3788 & 10107 & 0,9943 & $40,0110-0,0396 \mathrm{D}$ \\
\hline
\end{tabular}

Dapat dilihat dari bahwa nilai kapasitas jalan terbesar 10107 smp/jam dengan nilai koefisien determinasi 0,9943 terjadi pada pagi hingga sore hari / data gabungan.

Tabel 4. Analisis dengan pendekatan metode Greenshield depan JCC Senayan

\begin{tabular}{ccccccc}
\hline Waktu & Sff & B & Dj & C & R & Model \\
\hline $07.00-09.00$ & 66,9928 & $-0,1583$ & 423,2015 & 7088 & 0,9293 & $66,9928-0,1583 \mathrm{D}$ \\
$13.00-15.00$ & 76,4591 & $-0,2444$ & 312,8441 & 6215 & 0,9783 & $76,4591-0,2444 \mathrm{D}$ \\
$16.00-18.00$ & 64,5771 & $-0,1558$ & 414,4872 & 6692 & 0,8047 & $64,5771-0,1558 \mathrm{D}$ \\
Gabungan & 65,9140 & $-0,1595$ & 413,2359 & 6810 & 0,9593 & $65,9140-0,1595 \mathrm{D}$ \\
\hline
\end{tabular}

Nilai kapasitas jalan terbesar 7088 smp/jam yang terjadi pada jam 07.00-09.00 yang mempunyai nilai koefisien determinasi sebesar 0,9293.

Sedangkan kececapatan arus bebas yang didapat untuk kedua ruas jalan Gatot Subroto adalah 59,20 km/jam. Grafik hubungan kecepatan-kepadatan ruas Jalan Gatot Subroto sebrang JCC Senayan pada pagi hari dapat dilihat pada Gambar 1. Untuk grafik hubungan kecepatan-kepadatan ruas jalan Gatot Subroto sebrang JCC Senayan (siang hari) dapat dilihat pada Gambar 2, sedangkan grafik hubungan kecepatan-kepadatan rus jalan Gatot Subroto sebrang JCC Senayan (sore hari) terdapat pada Gambar 3. 


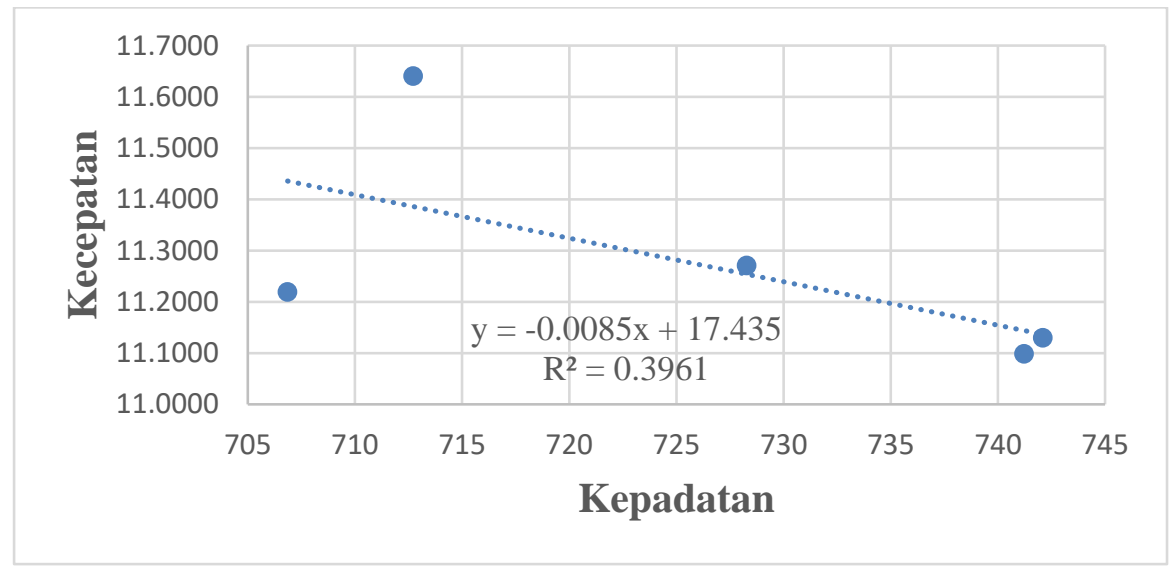

Gambar 1. Grafik hubungan kecepatan-kepadatan ruas jalan Gatot Subroto sebrang JCC Senayan (pagi hari)

Dapat dilihat pada Gambar 1 bahwa kepadatan yang terjadi pada pagi hari pukul 07.00-09.00 cukup padat sehingga kecepatan kendaraan tertinggi 11,65 km/jam

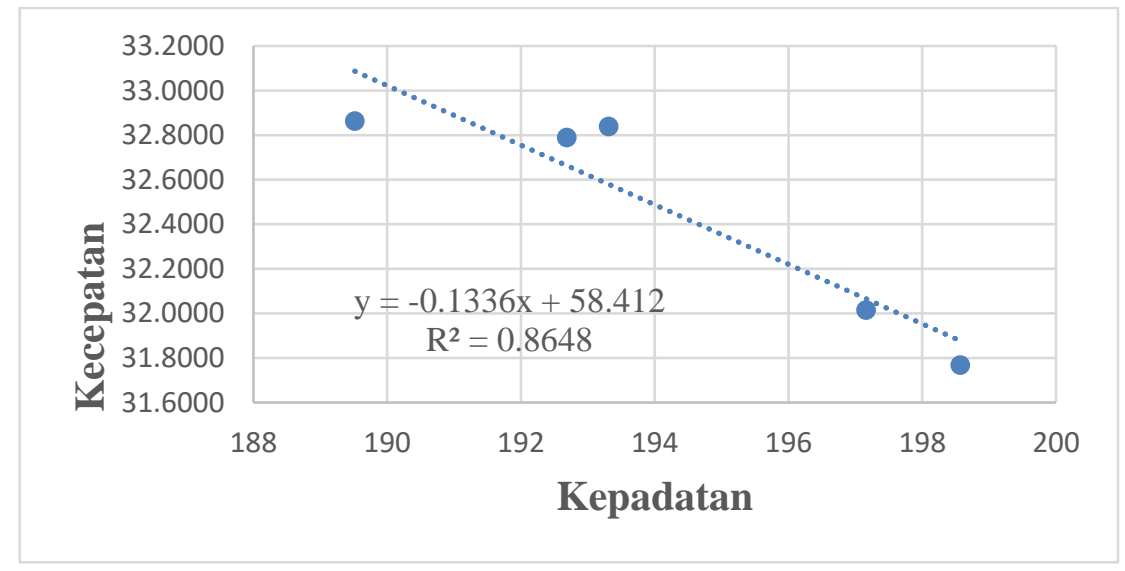

Gambar 2. Grafik hubungan kecepatan-kepadatan ruas jalan Gatot Subroto sebrang JCC Senayan (siang hari)

Kepadatan yang tidak terlalu tinggi, menyebabkan nilai kecepatan tidak terlalu rendah. Kecepatan tertinggi pada saat siang adalah $32,8 \mathrm{~km} / \mathrm{jam}$.

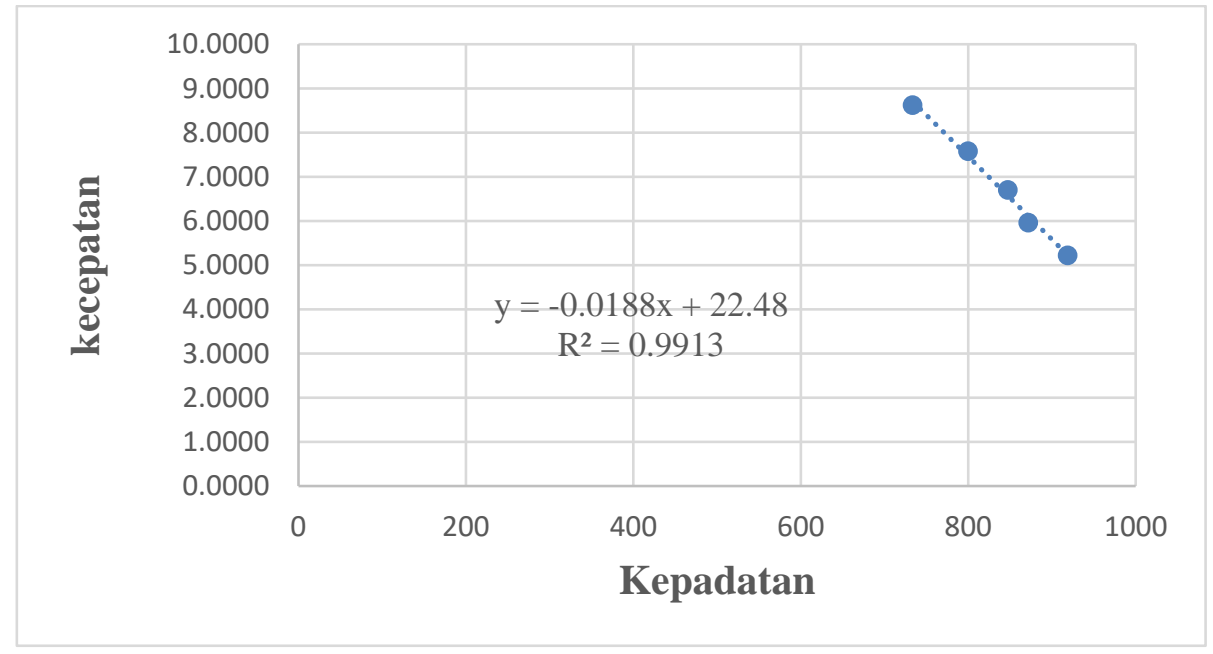

Gambar 3. Grafik hubungan kecepatan-kepadatan ruas jalan Gatot Subroto sebrang JCC Senayan (sore hari) 
Memiliki arus/volume kendaraan yang banyak sehingga dapat menyebabkan kepadatan pada ruas jalan tersebut, sehingga kecepatan yang dihasilkan sangat rendah.

Grafik hubungan kecepatan-kepadatan ruas jalan Gatot Subroto sebrang JCC Senayan (pagi-siang-sore hari) terdapat pada Gambar 4. Sedangkan grafik hubungan kecepatan-kepadatan ruas jalan Gatot Subroto depan JCC Senayan (pagi hari) terdapat pada Gambar 5.

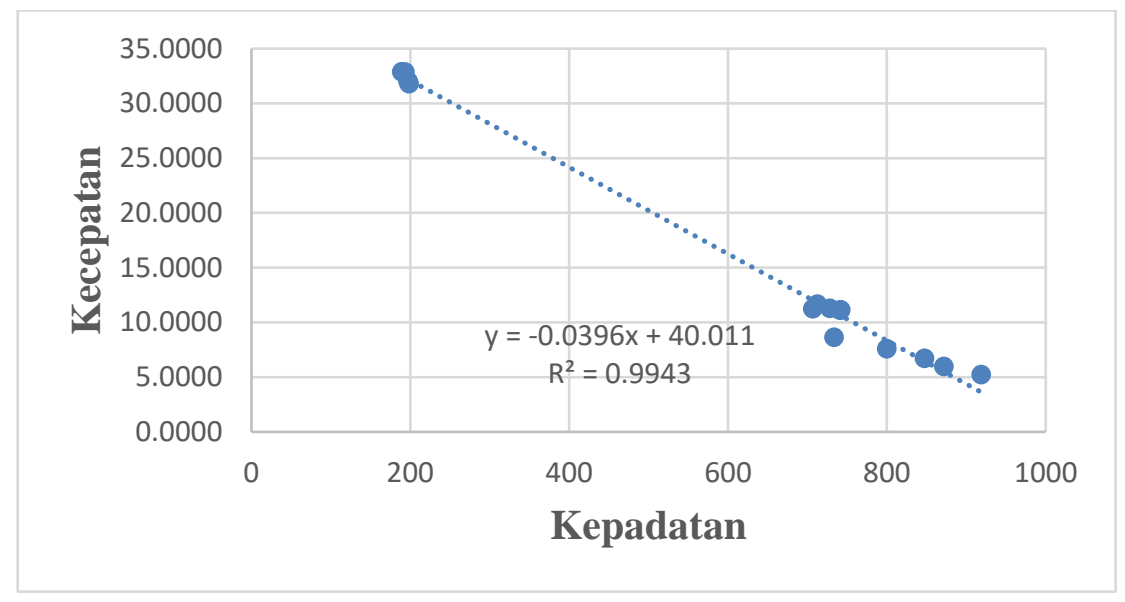

Gambar 4. Grafik hubungan kecepatan-kepadatan ruas jalan Gatot Subroto sebrang JCC Senayan (pagi-siang-sore hari)

Kepadatan terjadi di pagi hari dan juga sore hari terlihat sangat padat sehingga memiliki nilai kecepatan kurang dari $15 \mathrm{~km} / \mathrm{jam}$.

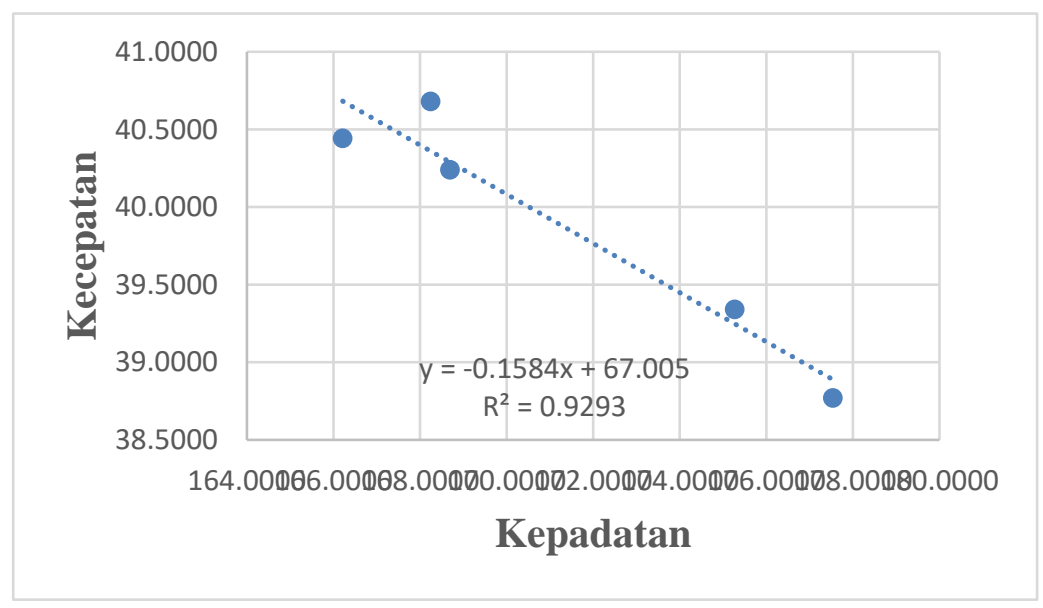

Gambar 5. Grafik hubungan kecepatan-kepadatan ruas jalan Gatot Subroto depan JCC Senayan (pagi Hari)

Pada ruas Jalan Gatot Subroto depan JCC Senayan (arah 2) nilai kepadatan tidak terlalu tinggi sehingga nilai kecepatan juga cukup tinggi, sehingga dapat diartikan bahwa jalan tersebut tidak macet.

Terlihat grafik hubungan kecepatan-kepadatan ruas jalan Gatot Subroto depan JCC Senayan (siang hari) pada Gambar 6 dan Gambar 7 merupakan grafik hubungan kecepatan-kepadatan ruas jalan Gatot Subroto depan JCC Senayan (sore hari). 


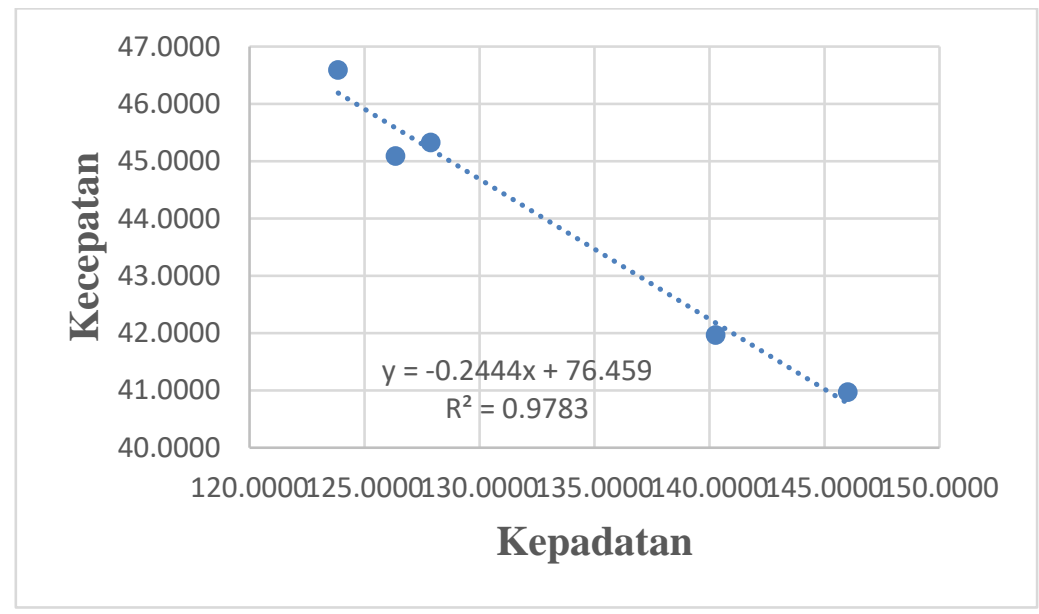

Gambar 6. Grafik hubungan kecepatan-kepadatan ruas jalan Gatot Subroto depan JCC Senayan (siang hari)

Pada saat siang hari jalanan tersebut juga cukup lengang sehingga tidak menimbulkan kepadatan yang berarti, jumlah kendaraan yang lewat pada jalan tersebut tidak cukup buanyak.

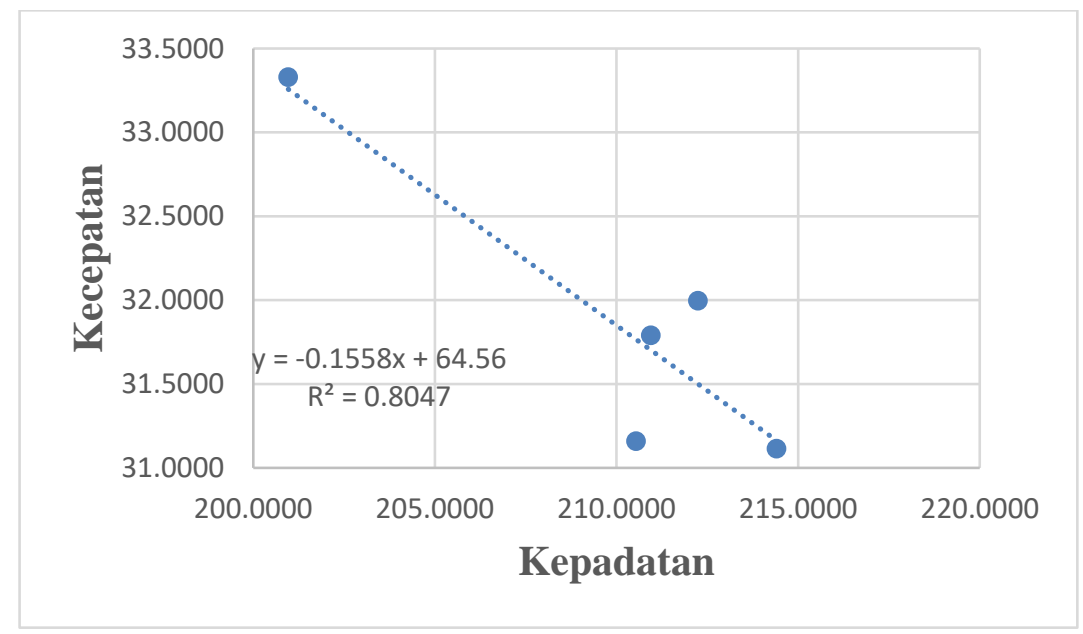

Gambar 7. Grafik hubungan kecepatan-kepadatan ruas jalan Gatot Subroto depan JCC Senayan (sore hari)

Dibandingkan dengan pagi hari dan juga siang hari, kepadatan mulai bertambah pada sore hari dikarenakan jam pulang kerja sehingga nilai kecepatan yang dihasilkan kendaraan bermotor kurang dari 33,5 km/jam.

Terdapat grafik hubungan kecepatan-kepadatan ruas jalan Gatot Subroto depan JCC Senayan (pagi-sing-sore hari) pada Gambar 8. 


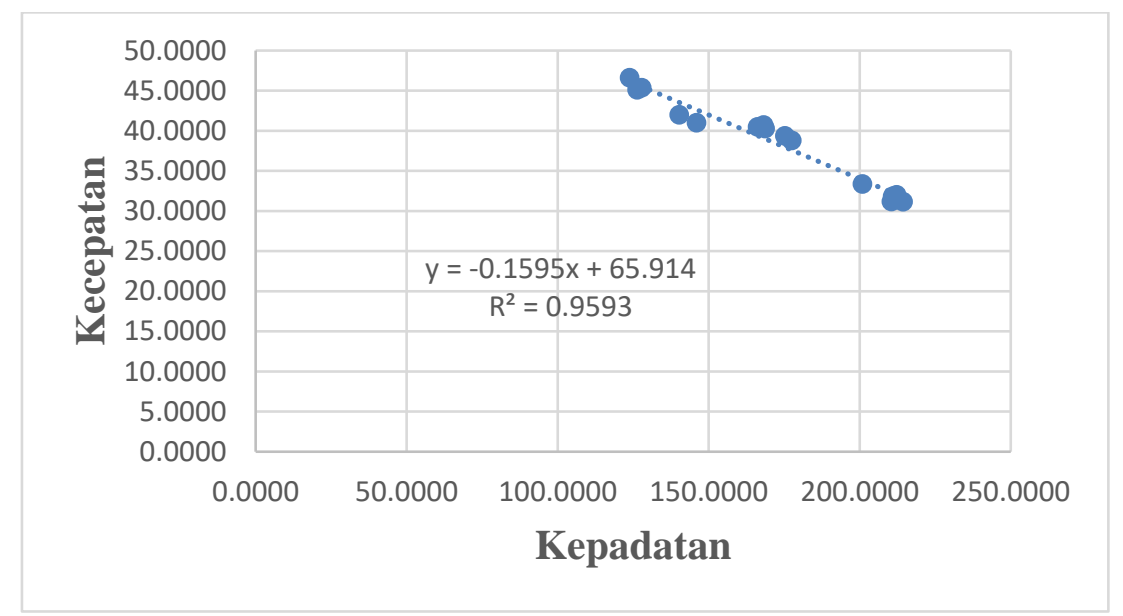

Gambar 8. Grafik hubungan kecepatan-kepadatan ruas jalan Gatot Subroto depan JCC Senayan (pagi-siang-sore hari)

Dari data gabungan (pagi-sore hari) kepadatan yang terjadi pada arah 2 (depan JCC Senayan) tidak sebanyak dengan nilak kepadatan pada arah 1, nilai kecepatan juga cukup tinggi.

Perbandingan nilai kapasitas jalan ruas Jalan Gatot Subroto sebrang JCC Senayan dapat terlihat pada Tabel 5 dibawah ini, dan Tabel 6 merupakan perbandingan nilai kapasitas jalan ruas Jalan Gatot Subroto depan JCC Senayan.

Tabel 5. Perbandingan nilai kapasitas jalan ruas jalan Gatot Subroto sebrang JCC Senayan

\begin{tabular}{ccccc}
\hline Ruas Jalan & Waktu & MKJI & Greenshield & Volume \\
\hline & $07.00-09.00$ & 4890,6 & 5349 & 8296 \\
JL.Gatot Subroto & $13.00-15.00$ & 4890,6 & 6382 & 6348 \\
Seberang JCC Senayan & $16.00-18.00$ & 4890,6 & 6721 & 6323 \\
& Gabungan & 4890,6 & 10107 & 8296 \\
\hline
\end{tabular}

Nilai kapasitas dengan menggunakan metode greenshield lebih besar dari volume maksimum pada arah 1, dapat dikatakan bahwa jalan tersebut masih efektif untuk dilalui.

Tabel 6. Perbandinga nilai kapasitas jalan ruas jalan Gatot Subroto depan JCC Senayan

\begin{tabular}{ccccc}
\hline Ruas Jalan & Waktu & MKJI & Greenshield & Volume \\
\hline & $07.00-09.00$ & 4890,6 & 7088 & 6895 \\
JL.Gatot Subroto Depan & $13.00-15.00$ & 4890,6 & 6215 & 5982 \\
JCC Senayan & $16.00-18.00$ & 4890,6 & 6692 & 6698 \\
& Gabungan & 4890,6 & 6810 & 6895 \\
\hline
\end{tabular}

Volume maksimum pada arah 2 terjadi pada saat pagi hari. Nilai kapasitas dengan menggunakan metode Greenshield lebih besar dari pada dengan menggunakan metode MKJI, maka dari itu metode Greenshield yang dipilih. Nilai kapasitas dengan menggunakan metode Greenshield lebih besar daripada nilai volume maksimum, sehingga jalan Gatot Subroto depan JCC Senayan juga masih efektif untuk dilalui.

Dari hasil yang telah diperhitungkan dan anlasisi yang telah dilakukan, maka diperoleh hasilnya sebagai berikut :

1. Dari hasil analisa diatas, bahwa nilai kapasitas jalan berdasarkan metode MKJI didapat hasil yang sama dikarenakan setiap ruas memiliki 6 lajur 2 jalur atau setiap arah 3 lajur 1 jalur, lebar setiap lajur 3,5 meter, memiliki nilai hambatan samping sangat rendah (very low).

2. Model yang digunakan pada arah 1 (Sebrang JCC Senayan) digunakan model gabungan VS=40,011 - 0,0396 $\mathrm{D}$, dan untuk arah digunakan model pada saat pagi hari $V S=66,9928-0,1583$ D. Permodelan diambil dengan membandingan nilai koefisien determinasi tertinngi dan juga nilai kapasitas jalan tertinggi. 
3. Didapat dari hasil analisa diatas bahwa nilai kapasitas jalan dengan menggunakan perhitungan pendekatan MKJI memiliki nilai 4890,6 smp/jam dimana nilai kapasitas lebih kecil dari pada nilai volume maksimum. Dapat disimpulkan bahwa ruas Jalan Gatot Subroto sudah tidak efektif lagi. Sedangkan dengan menghitung nilai kapasitas jalan menggunakan metode pendekatan Greenshield didapat nilai kapasitas jalan lebih besar dari volema maksimum, maka dapat dikatakan ruas jalan efektif.

\section{KESIMPULAN DAN SARAN}

\section{Kesimpulan}

Setelah penelitian ini selesai dibuat, maka kesimpulan yang diperoleh adalah :

1. Dari data analisis diatas maka dapat dihitung dengan menggunakan metode MKJI 1997 didapat nilai kapasitas jalan sebesar 4890,6 smp/jam.

2. Dengan menggunakan data diatas maka dapat mengetahui nilai kecepatan arus bebas (free flow) sebesar 59,1796 $\mathrm{km} / \mathrm{jam}$.

3. Dari hasil analisis dapat disimpulkan bahwa peningkatan kendaraan terjadi pada pukul $07.00-09.00$ dan pukul 16.00 - 18.00 yang disebabkan jumlah pengguna jalan meningkat drastic saat jam masuk dan jam pulang kerja atau yang disebut dengan rush hour

4. Perhitungan kapasitas dengan menggunakan hubungan antara kecepatan dan kepadatan untuk model Greenshield:

a. Ruas Jalan Gatot Subroto Sebrang JCC Senayan :

- Pagi hari

$V S=17,4350-0,0085 \mathrm{D} ; \mathrm{C} \quad=5349 \mathrm{smp} / \mathrm{jam}$

- Siang hari

$V S=58,4439-0,1338 \mathrm{D} ; \quad \mathrm{C} \quad=6382 \mathrm{smp} / \mathrm{jam}$

- Sore hari

$$
V S \quad=22,4881-0,0188 \mathrm{D} ; \quad \mathrm{C} \quad=6721 \mathrm{smp} / \mathrm{jam}
$$

- Gabungan

$$
V S \quad=40,0110-0,0396 \mathrm{D} ; \quad \mathrm{C} \quad=10107 \mathrm{smp} / \mathrm{jam}
$$

b. Ruas Jalan Gatot Subroto Depan JCC Senayan :

- Pagi hari

VS $=66,9928-0,1583 \mathrm{D} ; \quad \mathrm{C}=7088 \mathrm{smp} / \mathrm{jam}$

- Siang hari

$V S \quad=76,4591-0,2444 \mathrm{D} ; \quad \mathrm{C} \quad=6215 \mathrm{smp} / \mathrm{jam}$

- Sore hari

$$
\text { VS } \quad=64,5771-0,1558 \mathrm{D} ; \quad \mathrm{C} \quad=6692 \mathrm{smp} / \mathrm{jam}
$$

- Gabungan

$$
V S=65,9140-0,1595 \mathrm{D} ; \quad \mathrm{C} \quad=6810 \mathrm{smp} / \mathrm{jam}
$$

\section{Saran}

Setelah menganalisis penelitian ini, maka saran yang dihasilkan sebagai berikut :

1. Volume pada saat rush hour memiliki volume tertinggi sehingga dapat menyebabkan kemacetan lalu lintas, oleh sebab itu perlu dilakukannya manajemen lalu lintas oleh pemerintas setempat yang diharapkan bisa mengurangi/menanggulangi kemacetan yang terjadi.

2. Penelitian ini seharusnya melakukan survei lalu lintas setidaknya selama satu hari penuh untuk mendapatkan lebih banyak kondisi lalu lintas sehingga mendapatkan hasil yang maksimal di setiap ruas jalan.

3. Berdasarkan hasil pengamatan di lapangan jumlah kendaraan roda empat / roda dua lebih banyak menggunakan ruas jalan tersebut, disarankan untuk mengganti kendaraan pribadi beralih ke moda transportasi umum untuk mengurangi terjadinya kemacetan.

\section{DAFTAR PUSTAKA}

Departemen Pekerjaan Umum, Direktorat Jendral Bina Marga. Manual Kapasitas Jalan Indonesia. 1997.

Pribadi, Lucky Tulus. "Studi Hubungan Volume, Kecepatan Dan Kerapatan Pada Ruas Jalan Gatot Subroto Kota Cimahi." Jurnal Teknik, Volume 3 No.1 Mei (2004): 235. 
Risdiyanto. Rekayasa dan Manajemen Lalu Lintas Teori Dan Aplikasi. Yogyakarta: Leutikapro, 2014.

Salim, Abbas. Manajemen Transportasi. Jakarta: Raja Grafindo Prasada, 2000.

Tamin, Ofyar Z. Perencanaan dan Pemodelan Transportasi. Bandung: ITB, 2000. 